\title{
Earlier hatching and slower growth: a key to survival in the early life history of Norwegian spring spawning herring
}

\author{
Aril Slotte ${ }^{1, *}$, Åse Husebø ${ }^{1}$, Florian Berg ${ }^{1,2}$, Erling Kåre Stenevik ${ }^{1}$, Arild Folkvord ${ }^{1,2}$, \\ Petter Fossum ${ }^{1}$, Henrik Mosegaard ${ }^{3}$, Frode Vikebø ${ }^{1}$, Richard D. M. Nash ${ }^{1}$ \\ ${ }^{1}$ Institute of Marine Research (IMR), PO Box 1870 Nordnes, 5817 Bergen, Norway \\ ${ }^{2}$ Department of Biology, University of Bergen, PO Box 7800, 5020 Bergen, Norway \\ ${ }^{3}$ Technical University of Denmark, Kemitorvet, Bygning 202, 2800 Kgs. Lyngby, Denmark
}

\begin{abstract}
Faster growth in fish larvae is often associated with enhanced survival, and here we investigated whether surviving juvenile Norwegian spring spawning herring Clupea harengus L. generally come from a pool of fast-growing larvae. Growth after hatching was determined using daily otolith increment widths at distances of 37.5 to $137.5 \mu \mathrm{m}$ from the core in fish from 3 selected year classes (1991, 1992 and 1996) and compared among post-larvae (body lengths 20 to $30 \mathrm{~mm}$ ) sampled on the shelf in May-June and 0-group juveniles sampled during the autumn in fjords and Barents Sea nurseries. In general, daily otolith growth after hatching was significantly higher in the larvae rather than in the surviving population of 0-group herring at comparable sizes. Larvae with a more similar growth rate to that of 0-group were those that hatched early in the year, were the slowest growers and were located close to the coast and far to the north in mid-May. We therefore propose that survival until 0-group may increase by hatching earlier in the year. This may result in a faster northward larval drift in colder ambient temperature. Although this will induce slower growth, the mechanism behind increased survival is larval drift trajectories and early arrival in nursery areas prior to the increasing predation risk developing northwards during spring warming. However, size (not growth rate) may still be important, as early hatching also may result in earlier metamorphosis, despite the slower growth.
\end{abstract}

KEY WORDS: Herring $\cdot$ Larvae $\cdot$ Otolith $\cdot$ Growth $\cdot$ Drift Survival

\section{INTRODUCTION}

Recruitment in Norwegian spring spawning (NSS) herring is highly variable even at large stock sizes (Toresen \& Østvedt 2000). Variable mortality between larval and juvenile stages is often thought to be the main cause of inter-annual recruitment variability (Sissenwine 1984, Houde 1987, 1989). Recruitment is generally correlated with the number of offspring in the 0-group stage, but not in the early larval stage. Sætre et al. (2002a) showed that in NSS herring, even at the post-larval stage (age 30 to $90 \mathrm{~d}$ ) the number of offspring was not well correlated with

${ }^{*}$ Corresponding author: aril@hi.no

$\S$ Advance View was available online October 2, 2018 recruitment, whereas there was good correlation between 0 -group abundance and recruitment.

Two of the hypotheses explaining mortality in the larval and juvenile stages are the 'growth rate' and 'bigger is better' hypotheses (Takasuka et al. 2004). These hypotheses are based on size- and/or growthdependent survival; that is, fish larvae and the 0group are potential prey to a wide range of predators, but this risk decreases as the larvae and juvenile fish grow (Bailey \& Houde 1989). In most cases, this will favour high growth rates (Leggett \& Deblois 1994, Campana 1996, Meekan \& Fortier 1996, Hare \& Cowen 1997). In a recent study of North Sea herring,

(C) The authors 2019. Open Access under Creative Commons by Attribution Licence. Use, distribution and reproduction are unrestricted. Authors and original publication must be credited. 
Payne et al. (2013) demonstrated that the observed decrease in recruitment was accompanied by reduced larval growth rates, supporting the growthrate hypothesis. Mortality at the juvenile stage has been found to be strongly size-dependent (Caddy 1991), including in NSS herring (Barros \& Toresen 1994). Some results, however, show that certain predators in fact may choose the largest individuals (Litvak \& Leggett 1992, Pepin et al. 1992). In addition, it has been demonstrated that early-hatched larvae may experience lower predation pressure and have higher survival than those hatching later in the season, even if the early larvae experience lower temperatures and growth rates (Fortier \& QuinonezVelazquez 1998, Lapolla \& Buckley 2005, Nishimura et al. 2007). Husebø et al. (2009) supported this hypothesis using historic NSS herring data, demonstrating a negative correlation with hatching time estimated from larval surveys and recruitment.

The basis for the hypothesis of higher survival in early-hatched NSS herring is linked to the early life history of the stock, with a very wide spawning area and long distances between hatching locations and nursery areas. NSS herring are substrate spawners, utilising hard bottoms (shell sand, gravel, stones), which occur over a wide area along the Norwegian continental shelf (down to $250 \mathrm{~m}$ depth) from 58 to $70^{\circ} \mathrm{N}$ (Slotte 1999, Sæetre et al. 2002b). The majority of the larvae drift northwards to the Barents Sea nursery area (Holst \& Slotte 1998). However, retention over bank areas is common (Sætre et al. 2002a), and a minor portion of the larvae are entrained into coastal and fjordic nursery areas along the coast (Holst \& Slotte 1998). Hence, NSS herring larvae generally drift over large distances between the hatching and nursery areas, experiencing a wide range of environmental conditions and variable predation pressure. Regarding the potential mechanism between early hatching and larval survival, Husebø et al. (2009) concluded that the range and abundance of important predators of herring larvae would generally tend to increase and become more active as spring warming progresses northwards along the coast, and that early hatching and rapid northward drift could therefore lead to reduced predator overlap in time and space. However, Husebø et al. (2009) could not exclude the possibility that early spawning may have advantages that are more related to ambient temperatures, feeding success and growth than to predation pressure.

Following this, Vikebø et al. (2010) carried out model simulations of NSS herring to test the effects of early hatching at the main spawning grounds off
Møre (62 to $64^{\circ} \mathrm{N}$ ) on larval drift routes and ambient temperature. The study indicated that early spawning leads to faster northward displacement of larvae, with a drift route closer to the coast in lower ambient temperatures compared with larvae hatched later in spring. Hence, it was concluded that early hatching would not be favourable due to temperaturedependent growth, although the possibility of improved feeding conditions could not be excluded. Later, Vikebø at al. (2012) tested the potential overlap with prey by exploring the development of phytoplankton blooms along the coast. They found a delay in the bloom with increasing latitude of $37 \mathrm{~d}$ within the spawning habitat of NSS herring. Overlap between larval hatching and blooms was clearly highest at the main spawning grounds in the south (62 to $64^{\circ} \mathrm{N}$ ), suggesting that match with prey availability may be an important factor in the selection of spawning grounds by NSS herring, and that early spawning only would be successful if the herring migrated southwards to spawn.

Since the early 1990s, otolith microstructure analyses have been used in many studies to examine early life growth, condition and survival of NSS herring (Moksness \& Fossum 1992, Fossum \& Moksness 1995, Moksness et al. 1995, Folkvord et al. 2004). Based on these studies it has become clear that discernible increments observed in larval herring otoliths outside the core area typically are due to daily growth. Thus, increment size at some distance outside the core area will reflect the daily otolith growth at a given otolith size, and indirectly, larval size. However, due to the variable otolith growth immediately outside the core area, precise age and corresponding hatching day estimations are not possible without assumptions about the initial otolith growth in the first days after hatching (Fox et al. 2003). Moreover, the results clearly demonstrate that the daily growth of the larvae increases with temperature when food is available (e.g. Folkvord et al. 2004).

The principal hypothesis tested in the present study was that fast growth rate is a determinant of survival through the larval drift phase between the spawning and nursery grounds. Growth rate comparisons were undertaken using daily otolith increment widths at selected distances from the core, corresponding to periods of larval drift, for larvae and the surviving 0-group stages. The 1991, 1992 and 1996 year classes were chosen for this study as they characterised the variability in the stock, with the 1991-1992 year classes representing years with early hatching and high recruitment in comparison to the 
late hatching and low recruitment in 1996 (Husebø et al. 2009). It is also important to note that the 1991-1992 year classes grew up in the Barents Sea, whereas the 1996 year class was relatively more abundant in the fjords (Husebø et al. 2007).

\section{MATERIALS AND METHODS}

\subsection{Larval and environmental sampling}

Data used in the present study on larval distribution, density and their ambient temperatures at sampling, as well as individual larval data used for analyses of daily otolith growth, were collected during annual field studies off the Norwegian coast in May (Nedreaas 1995). The survey timing, coverage, stations and sampling in 1991, 1992 and 1996 are given in Table 1 and Figs. 1 \& 2. After 1992, the larval survey design for the shelf area was changed to only include sampling along a single south-north transect (Figs. 1 \& 2). Although this means that the larval sampling in 1996 was not consistent with 1991-1992 spatially and temporally, it was still chosen for interesting comparative reasons; 1991 and 1992 were years with early hatching and good recruitment, whereas 1996 was a year with a very late and broad hatching (see Fig. 4) and low recruitment (Husebø et al. 2009). In fact, 1996 was a year where the main part of the 1991-1992 year classes carried out their first spawning, and this happened in a second, later spawning wave (Slotte et al. 2000), thus the broad hatching curve. We found that the south-north sampling transect in 1996 overlapped with the 1991-1992 distributions and represented quite well the average larvae present at that time. We acknowledge that it is not directly comparable with the broader sampling of larvae in 1991-1992, but we have chosen to treat the 3 years equally in the analyses, as we do not consider that the spatial differences in sampling would significantly influence the main results and conclusions.

Table 1. An overview of years, areas and periods of sampling of the different Norwegian spring spawning herring life stages, along with number of stations and individuals analysed for daily otolith growth. See Fig. 1 for detailed positions of samples

\begin{tabular}{|llcccc|}
\hline Year & Area & Period & Life stage & $\begin{array}{c}\text { No. of } \\
\text { stations }\end{array}$ & $\begin{array}{c}\text { No. of } \\
\text { individuals }\end{array}$ \\
\hline 1991 & Norwegian shelf & 7-24 May & Larvae & 23 & 212 \\
1991 & Fjords south of $68^{\circ} \mathrm{N}$ & 21-28 Nov & 0-group & 7 & 59 \\
1991 & Fjords north of $68^{\circ} \mathrm{N}$ & 7-10 Nov & 0-group & 4 & 58 \\
1991 & Barents Sea & 28 Aug, 13 Sep & 0-group & 4 & 65 \\
1992 & Norwegian shelf & 08-13 May & Larvae & 19 & 272 \\
1992 & Fjords north of $68^{\circ} \mathrm{N}$ & 5-12 Nov & 0-group & 4 & 62 \\
1996 & Norwegian shelf & 11-12 Jun & Larvae & 7 & 314 \\
1996 & Fjords north of $68^{\circ} \mathrm{N}$ & 29 Nov-10 Dec & 0-group & 9 & 69 \\
\hline
\end{tabular}

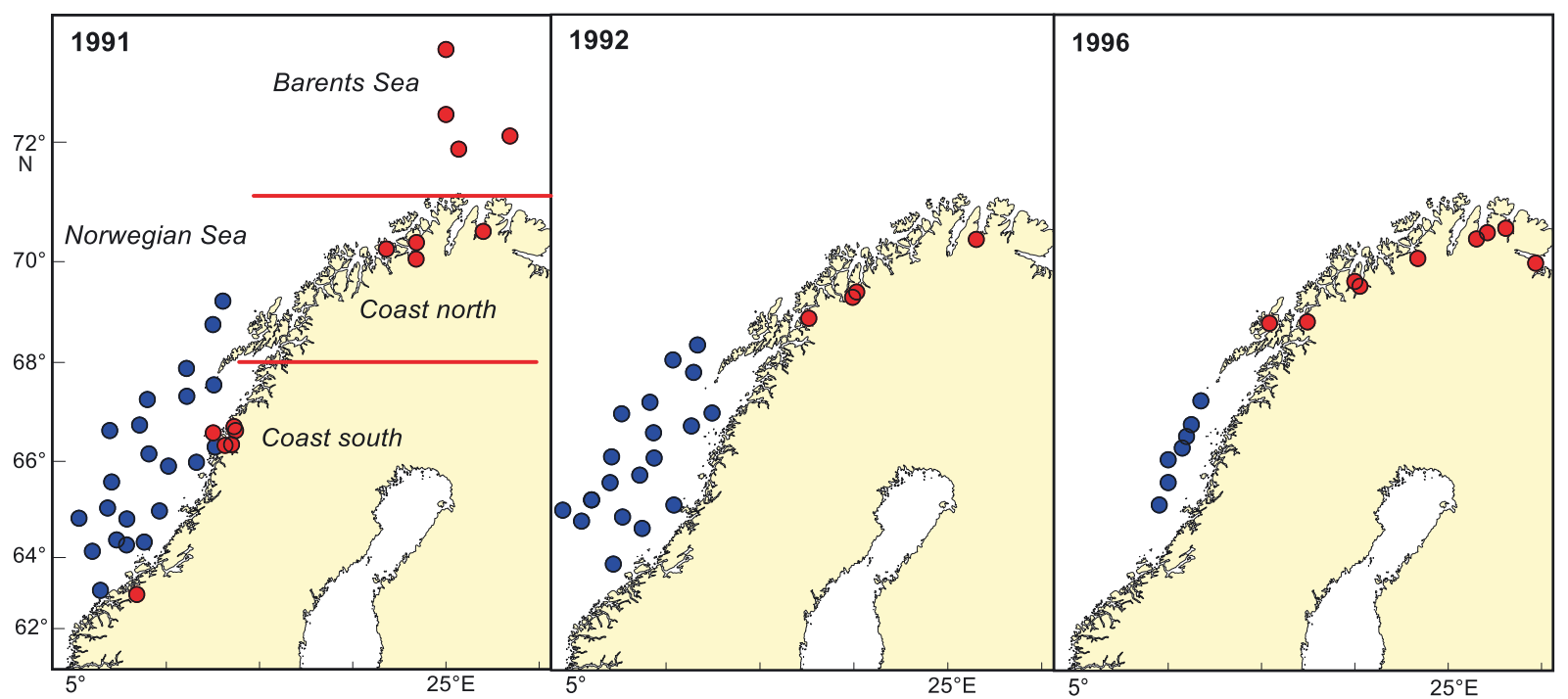

Fig. 1. Sampling sites of otoliths in larval (blue dots) and 0-group (red dots) Norwegian spring spawning herring in 1991,1992 and 1996. Red lines: limits between areas used for spatial comparison of 0-group otolith growth (coast south, coast north and Barents Sea) 
Water column structure at each station was measured with a CTD (Seabird SBE911) with a rosette. Temperature and salinity at $20 \mathrm{~m}$ depth was taken as representative of the sampling station. Sampling of larvae was undertaken using a MIK (2 m Midwater Ring Trawl; ICES 2013), multiple opening/closing net and environmental sensing system (MOCNESS; Wiebe et al. 1985) and pelagic trawl. Nedreaas (1995) suggested that the capelin trawl (modified Harstad trawl) gave the most representative estimates of postlarval densities. Also, Fossum (1994) concluded that there was no significant difference in herring length distributions sampled with the MIK and the Harstad trawl, and therefore samples collected with the Harstad trawl gave reliable qualitative estimate of true herring larvae distribution and size structure present in the sampling area. The modified Harstad trawl (Godø et al. 1993) had an $8 \mathrm{~mm}$ mesh cod end liner. This trawl was towed at 3 nautical miles (nmi) $\mathrm{h}^{-1}$ for $0.5 \mathrm{nmi}$ with the towline at the surface, then $0.5 \mathrm{nmi}$ at $20 \mathrm{~m}$, and $0.5 \mathrm{nmi}$ at $40 \mathrm{~m}$ depth. The total towing distance was 1.5 to $1.8 \mathrm{nmi}$. Trawling was undertaken during both day and night. The entire catch was sorted and counted, and density in terms of numbers per trawl hour was estimated by fish species. In addition, a random sub-sample of each species was measured (fork length, nearest $1 \mathrm{~mm}$ ), and representative samples retained for further analyses, e.g. otolith microstructure analyses.

\subsection{0-group sampling}

The 0-group NSS herring from fjord and Barents Sea nurseries and from the same cohorts as the larvae (1991, 1992 and 1996) were selected for otolith microstructure analyses (Table 1, Fig. 1). The material was selected from the large archive of NSS herring otoliths held by the Institute of Marine Research (IMR), and all 0-group samples were collected with R/V 'Michael Sars' using a standard Harstad trawl, towed at $3.5 \mathrm{nmi} \mathrm{h}^{-1}$. To ensure a wide latitudinal range of data, otoliths were selected along the coastline (classified as coast south and north of $68^{\circ} \mathrm{N}$ ) as well as in the Barents Sea (only in 1991) (Fig. 1, Table 1). It would have been preferable to also have representative otolith data from the 0-group in the Barents Sea in 1992 and 1996, as the Barents Sea is the main nursery area and only a minor part of the stock grows up in the fjords (Holst \& Slotte 1998). However, otoliths are not routinely sampled in the Barents Sea during the annual August-September 0-group trawl survey. The exception was from 4 trawl stations taken by the R/V 'G.0. Sars' in 1991. These were included in the analysis as representative of the main part of the year class growing up in the Barents Sea.

\subsection{Otolith microstructure analyses}

The otolith microstructure data from larvae were a part of P. Fossum's previously published and ongoing work, and he made these available at the start of the present study. The herring larvae he and his team analysed were preserved in $80 \%$ buffered ethanol immediately after capture. The methodology used for preparing and reading the otoliths is laid out in Moksness \& Wespestad (1989). All increments, from the core to the edge of the otolith were measured.

In the case of 0 -group herring, both sagittal otoliths were removed immediately after sampling, placed in black trays and embedded in histokitt resin for regular age reading. For this study, the otoliths selected for microstructure analyses were removed from these black trays with a scalpel and mounted in thermoplastic cement on glass slides. During the mounting process, heating was used on the glass slides and minor histokitt remains mixed with the thermoplastic cement. In order to examine the microstructure of 0-group otoliths we used grinding and polishing methods described by Mosegaard \& Madsen (1996) (Fig. 3). Polished otoliths were examined using a Leica DMLB light microscope (Leica Microsystems) at $400 \times$ and $800 \times$ magnification connected to a digital camera and a computer. Pictures $(3840 \times 3072$ pixels $)$ of the otoliths were taken with a digital camera (Nikon DXM 1200F) with use of Eclipse.net software (Laboratory Imaging). The width of each otolith increment was measured as the distance between 2 opaque zones using the image analysing software Image-Pro Plus v.4.0 (Media Cybernetics). Examination of the otoliths was carried out along the same transect from the core to the posterior margin along the longest readable axis, and increments were measured at distances from the core up to a maximum of $250 \mu \mathrm{m}$.

\subsection{Data analyses}

Increments less than $37.5 \mu \mathrm{m}$ from the otolith core were excluded from further analyses because of the uncertainty of increments and widths in the period immediately after hatching (Campana \& Moksness 1991, Fox et al. 2003). An otolith size of $37.5 \mu \mathrm{m}$ in 
Fig. 2. Norwegian spring spawning herring larval sampling sites combined with CTD casts (black dots) in 1991 and 1992. The corresponding larval density (in terms of numbers per trawl hour) and temperature at $20 \mathrm{~m}$ depth is mapped for both years along with positions of otolith sampling (red dots). Positions with otolith sampling in 1996 are marked in the 1991 map (yellow dots). Special areas (Areas 1-4) for spatial comparisons of larval otolith growth with 0-group are marked with red squares
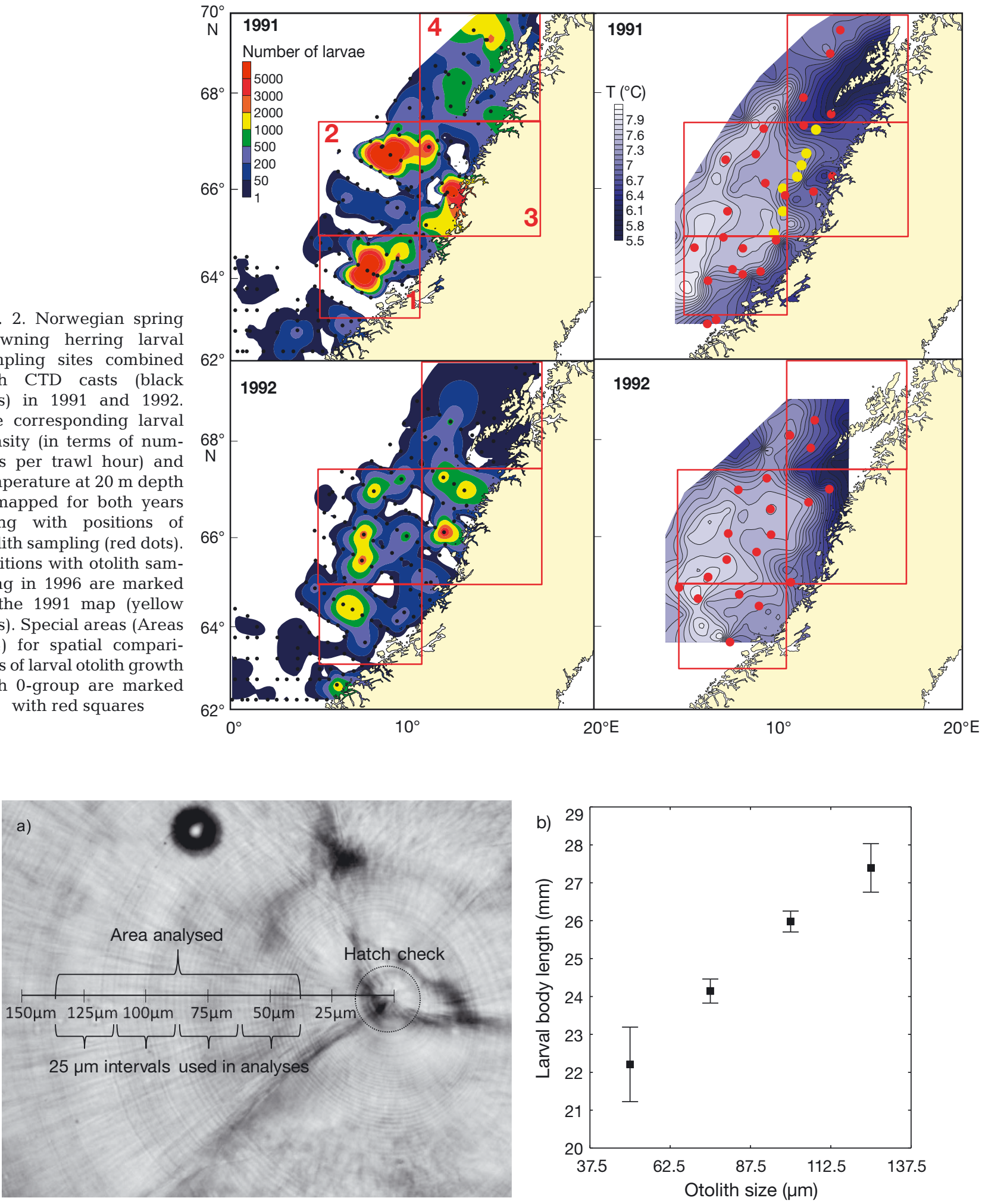

Fig. 3. (a) Daily growth increments in a ground and polished otolith from 0-group Norwegian spring spawning herring. The hatch check (dotted circle) and distances from the core are shown, and the area and intervals used in the analyses of daily otolith growth in larvae and 0-group herring are marked. (b) Mean larval body length related to otolith size in the 1991-1992 material, where otolith sizes are grouped into the same intervals as used in the analyses for the present study. The interval $37.5-137.5 \mu \mathrm{m}$ from the otolith core analysed for daily growth of 0-group corresponds to larval sizes of between 20 and $30 \mathrm{~mm}$ body length. Error bars are $95 \%$ confidence limits 
herring corresponds in general to a larval length of approximately $20 \mathrm{~mm}$ (Folkvord et al. 2004, 2009), also fitting well with the data on larvae used in the present study (Fig. 3).

Following this, any aging of the larvae would be considered uncertain, and for the 0-group the lack of precise measurements of increments all the way from the core to the edge of the ground and polished otolith would also prevent any aging in number of days. Still, a link between age and sampling time of larvae was necessary for analysing effects of hatching time on the daily otolith growth. To get a proxy for the age of larvae, we used the total number of increments ( $\left.N_{\text {increments }}\right)$ beyond $37.5 \mu \mathrm{m}$ from the core up to the edge of the otoliths. Due to the survey design, northern stations were sampled 7 to $17 \mathrm{~d}$ later than southern stations, resulting in different catching dates $\left(\right.$ Day $\left.y_{\text {Catch }}\right)$. To account for this timing difference, we based our analyses on standardised time within a year. This was done by estimating the day of year when the larvae had attained an otolith size of $37.5 \mu \mathrm{m}\left(\operatorname{Day}_{37.5}\right)$ as:

$$
\operatorname{Day}_{37.5}=\text { Day }_{\text {Catch }}-N_{\text {increments }}
$$

Further, within each year class, the earliest day of year with sampled larvae attaining an otolith radius of $37.5 \mu \mathrm{m}$ was defined as:

$$
\operatorname{Minimum}\left(\operatorname{Day}_{37.5}\right)=\text { Day } 1
$$

with all other larval increment data being re-scaled to this day, hereafter termed relative hatching day. This allowed for a direct comparison of larval otolith growth between different relative hatching times within a year class independent of the varying sampling times.

Increments greater than $137.5 \mu \mathrm{m}$ from the otolith core were also excluded from further analyses, due to the lack of overlap between larvae and 0-group data at these distances. Frequency distributions of Day 37.5 suggested that the larval material came from a wide range of hatching days, and with a broader range in 1996 than in 1991-1992 (Fig. 4), also leading to variable otolith size distributions. The number of larval individuals available for analyses of daily increments was significantly reduced when growth at increasing distances from the otolith core was analysed (Table 2), where in the end only data from the earliest hatched larvae were available. At distances greater than $137.5 \mu \mathrm{m}$ from the core, the number of available larvae with large enough otoliths was very small (1991 and 1996), or even lacking (1992).

Within the chosen limitations of analyses of daily otolith increments from 37.5 to $137.5 \mu \mathrm{m}$ from the core, the data were grouped into $25 \mu \mathrm{m}$ intervals (i.e.
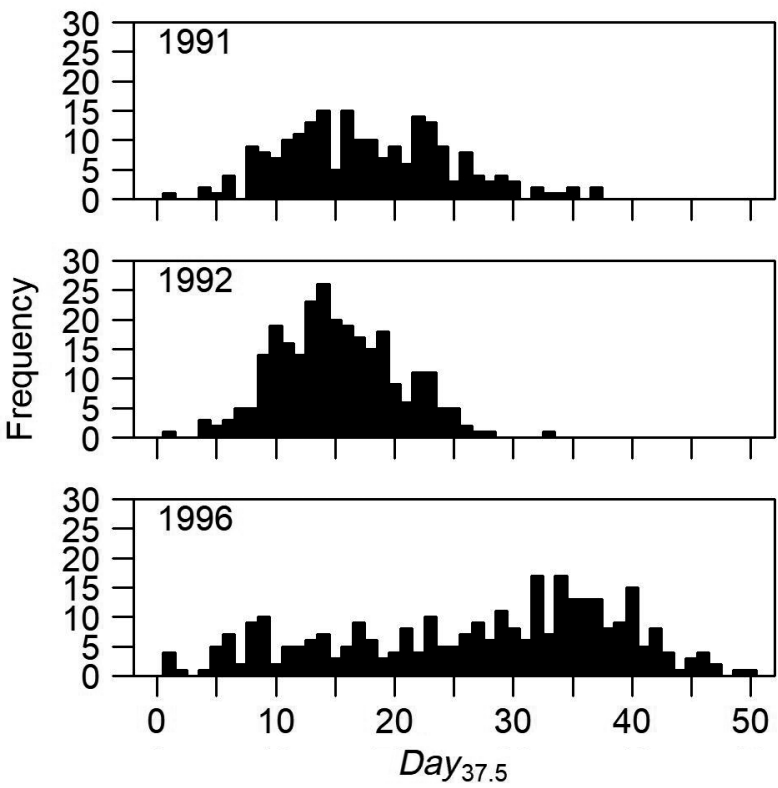

Fig. 4. Relative hatching day (Day ${ }_{37.5}$ ) distribution of Norwegian spring spawning herring larvae from the 1991-1992 and 1996 year classes sampled in May and June

Table 2. Number of Norwegian spring spawning herring larvae analysed by year class and increment interval, and the corresponding mean proxy for age as total number of increments $\geq 37.5 \mu \mathrm{m}$ ( $\left.N_{\text {increment }}\right)$ as well as mean relative hatch day standardised to the day of year when the larvae attained an otolith size of $37.5 \mu \mathrm{m}$ (Day37.5). Increments are grouped into intervals of $25 \mu \mathrm{m}$ from the otolith core; therefore, interval 50 is $37.5<62.5 \mu \mathrm{m}$ from the core, interval 75 is 62.5 $<87.5 \mu \mathrm{m}$ from the core, etc. (see Fig. 3). Number of larvae analysed at interval 150 are also shown, but not used for further statistical analyses due to the low number of individuals available

\begin{tabular}{|ccccc|}
\hline $\begin{array}{c}\text { Year } \\
\text { class }\end{array}$ & $\begin{array}{c}\text { Interval } \\
(\mu \mathrm{m})\end{array}$ & $\mathrm{N}$ & $N_{\text {increment }}$ & Day $_{37.5}$ \\
\hline 1991 & 25 & 212 & 25.9 & 17.7 \\
1991 & 50 & 212 & 25.9 & 17.7 \\
1991 & 75 & 197 & 27.3 & 16.7 \\
1991 & 100 & 131 & 31.8 & 13.9 \\
1991 & 125 & 45 & 38.4 & 10.0 \\
1991 & 150 & 16 & 41.0 & 7.0 \\
1992 & 25 & 272 & 21.2 & 15.2 \\
1992 & 50 & 272 & 21.2 & 15.2 \\
1992 & 75 & 249 & 22.1 & 14.4 \\
1992 & 100 & 86 & 27.5 & 10.1 \\
1992 & 125 & 1 & 35.0 & 4.0 \\
1992 & 150 & 0 & & \\
1996 & 25 & 314 & 23.5 & 26.8 \\
1996 & 50 & 313 & 23.5 & 26.8 \\
1996 & 75 & 262 & 26.4 & 23.9 \\
1996 & 100 & 148 & 33.9 & 16.5 \\
1996 & 125 & 67 & 40.8 & 9.8 \\
1996 & 150 & 11 & 48.1 & 3.4 \\
\hline
\end{tabular}


distance $50 \mu \mathrm{m}$ represents the interval $37.5<62.5 \mu \mathrm{m}$ and 75 represents the interval $62.5<87.5 \mu \mathrm{m}$, etc.; Fig. 3, Table 2). Each individual larva and 0-group herring was assigned a mean increment width over the $25 \mu \mathrm{m}$ intervals, and these mean values were used for graphic visualizations in the figures. However, for statistical analyses, all single measurements of increments at the individual larval level were included.

Statistics and graphical output was undertaken in the R software (R Core Team 2017). Otoliths from 20 randomly selected 0-group individuals from several stations were analysed twice to determine the precision of measurements of daily otolith growth. Based on a linear effects model with individual otolith as a random factor, there was no statistical difference between the results of the 2 measurements (ANOVA: $F=$ $0.60, \mathrm{df}=1, \mathrm{p}=0.44$ ), suggesting that the measurements were reliable. To test for differences in daily otolith growth, linear mixed-effects models were run with increment width as the dependent variable. The optimal structure of the random effects (a) was tested using a likelihood ratio test based on the models fitted by restricted maximum likelihood estimations (REML) (Zuur et al. 2009). For all models, the structure of the random effect was station/individual otolith. Furthermore, based on REML fits, the fixed effects structure was optimized using marginal $F$-statistics (Pinheiro \& Bates 2000). For all models, both the random effect $a$ and the residual $\varepsilon$ were assumed to be normally distributed with mean of zero and variance $\sigma^{2}$. All mixedeffects models were fitted using the 'Ime' function within the R package 'nlme' (Pinheiro \& Bates 2000). The first model had the form of:

$$
\begin{aligned}
\text { Width }= & \alpha+\beta_{1} \times \text { dis }+\beta_{2} \times \text { Group }+\beta_{3} \times \text { Yclass } \\
& +\beta_{4} \times \text { dis } \times \text { Group }+\alpha+\varepsilon
\end{aligned}
$$

Increment distance from the core (dis), year class (Yclass) and life stage (Group; larval and three 0groups) were included as categorical factors in the fixed effects structure. The next models were run for each year class individually and had the following form:

$$
\begin{aligned}
& \text { Width }=\alpha+\beta_{1} \times \text { dis }+\beta_{2} \times \operatorname{Day}_{37.5} \\
& +\beta_{3} \times \text { dis } \times \operatorname{Day}_{37.5}+a+\varepsilon \\
& \begin{aligned}
\text { Width } & =\alpha+\beta_{1} \times \text { dis }+\beta_{2} \times \text { Area }+\beta_{3} \\
& \times \text { dis } \times \text { Area }+a+\varepsilon
\end{aligned}
\end{aligned}
$$

Relative hatching day (Day $\left.{ }_{37.5}\right)$ and sampling area (Area; see areas in Fig. 2) were included as categorical variables in the fixed effects structure. The hatching day was divided into the following intervals: $<15,15$ $<25,25<35, \geq 35$ and the 0 -group. Note that due to the use of area and hatching day as categorical variables it was not possible to run a model with both variables included. A model with hatching day and area included would allow for a direct comparison of the effect on otolith growth of each variable. p-values are given in the text in cases where the life stage, hatching day $\left(D_{1} y_{37.5}\right)$ or area significantly influenced the otolith increment width. Significant differences among several variables were identified using Tukey's HSD tests.

\section{RESULTS}

Daily otolith growth over the analysed interval (37.5 to $137.5 \mu \mathrm{m}$ from the core) was significantly higher in the larvae than in the surviving population of 0-group herring when tests were run for all 3 year classes (ANOVA: $F=88.4, \mathrm{df}=3, \mathrm{p}<0.001$ ) (Fig. 5). When comparing raw data points of the measured increment widths (Fig. 5), there was a clear overlap between the larval and 0-group data, but at the same time a tendency of the 0-group to have some measurements of low daily growth outside of those observed in the larvae, especially at distances 62.5 to $112.5 \mu \mathrm{m}$ from the core. No significant difference in daily otolith growth was found between 0-group herring of the 1991 year class collected in southern and northern fjords and in the Barents Sea (Tukey's HSD tests: $p>0.2$ ). Hence, for the rest of the statistical testing, 0-group data were merged regardless of area of collection.

A closer examination of the daily otolith growth in larvae revealed that relative hatching day ( Day $_{37.5}$ ) was a significant factor within each year class (ANOVA 1991: $F=37.0, \mathrm{df}=4, \mathrm{p}<0.001 ; 1992: F=$ 26.5, df $=4, \mathrm{p}<0.001 ; 1996: F=537.5, \mathrm{df}=5, \mathrm{p}<$ $0.001)$; growth tended to decrease with earlier hatching of the larvae (Fig. 6). When testing for differences between larvae and 0-group at different hatching day intervals, the daily otolith growth over the analysed interval ( 37.5 to $137.5 \mu \mathrm{m}$ from the core) did not differ significantly between the earliest hatched larvae (hatching days $\leq 25$ ) and the 0 -group (Tukey's HSD tests: $p>0.05$ ) in all 3 year classes.

The observed reduced growth in the earliest hatched larvae was further analysed by comparing the daily otolith growth between larvae from 4 different sampling areas (see areas in Fig. 2) (Fig. 7). This spatial analysis revealed that sampling area (location of the individuals) had a significant effect (ANOVA 1991: $F=99.4, \mathrm{df}=4, \mathrm{p}<0.001 ; 1992: F=112.6, \mathrm{df}=4$, $\mathrm{p}<0.001 ; 1996: F=696.1, \mathrm{df}=4, \mathrm{p}<0.001)$ on the larval otolith growth, with a tendency for growth to 

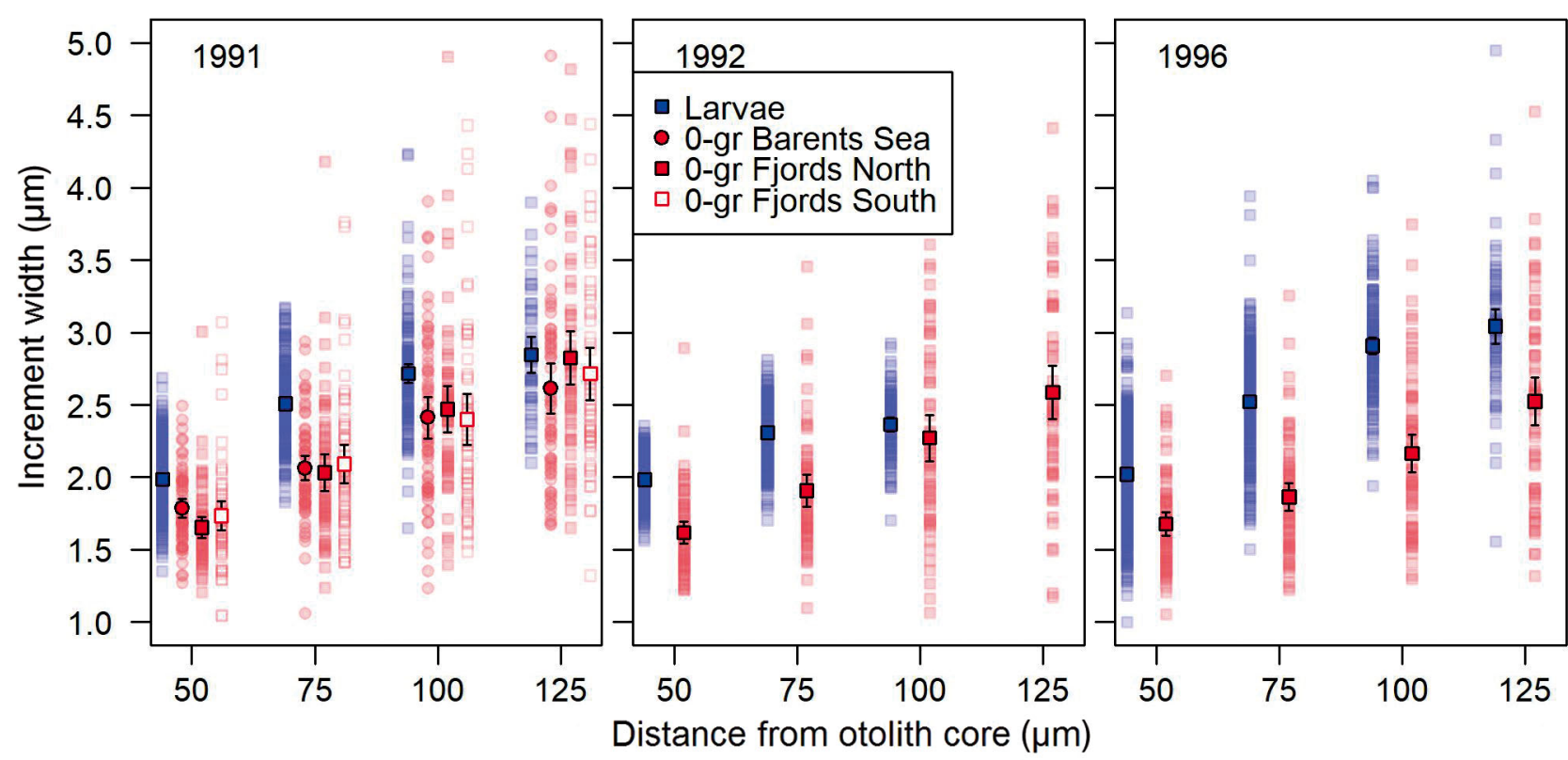

Fig. 5. Daily otolith increment width (mean $\pm 95 \%$ CI) related to the distance from the otolith core and life stage analysed for the Norwegian spring spawning herring year classes 1991, 1992 and 1996. Raw data points of all measurements are also shown, where one data point represents one measurement of the daily increment width in single larvae within the selected distance interval from the otolith core. In 1991 the 0-group data are split into Barents Sea, and fjords in the north and south

decrease going northeast from Area 1 to Area 4. The spatial effect was clearest for the 1991 year class, where there were no differences in otolith growth between larvae from Area 3, Area 4 and the surviving population of 0 -group herring (Tukey's HSD test: $\mathrm{p}>0.05)$. In the 1992 and 1996 year classes the growth between larvae and 0-group herring differed regardless of larval sampling area (Tukey's HSD test: $\mathrm{p}<0.001$ ).

Corresponding to the observed spatial differences in daily otolith growth, there was also an area effect on larval hatching day and total larval body length (ANOVA Day ${ }_{37.5}: F=98.6, \mathrm{df}=3, \mathrm{p}<0.001$; ANOVA length: $F=15.8, \mathrm{df}=3, \mathrm{p}<0.001$ ); the earliest
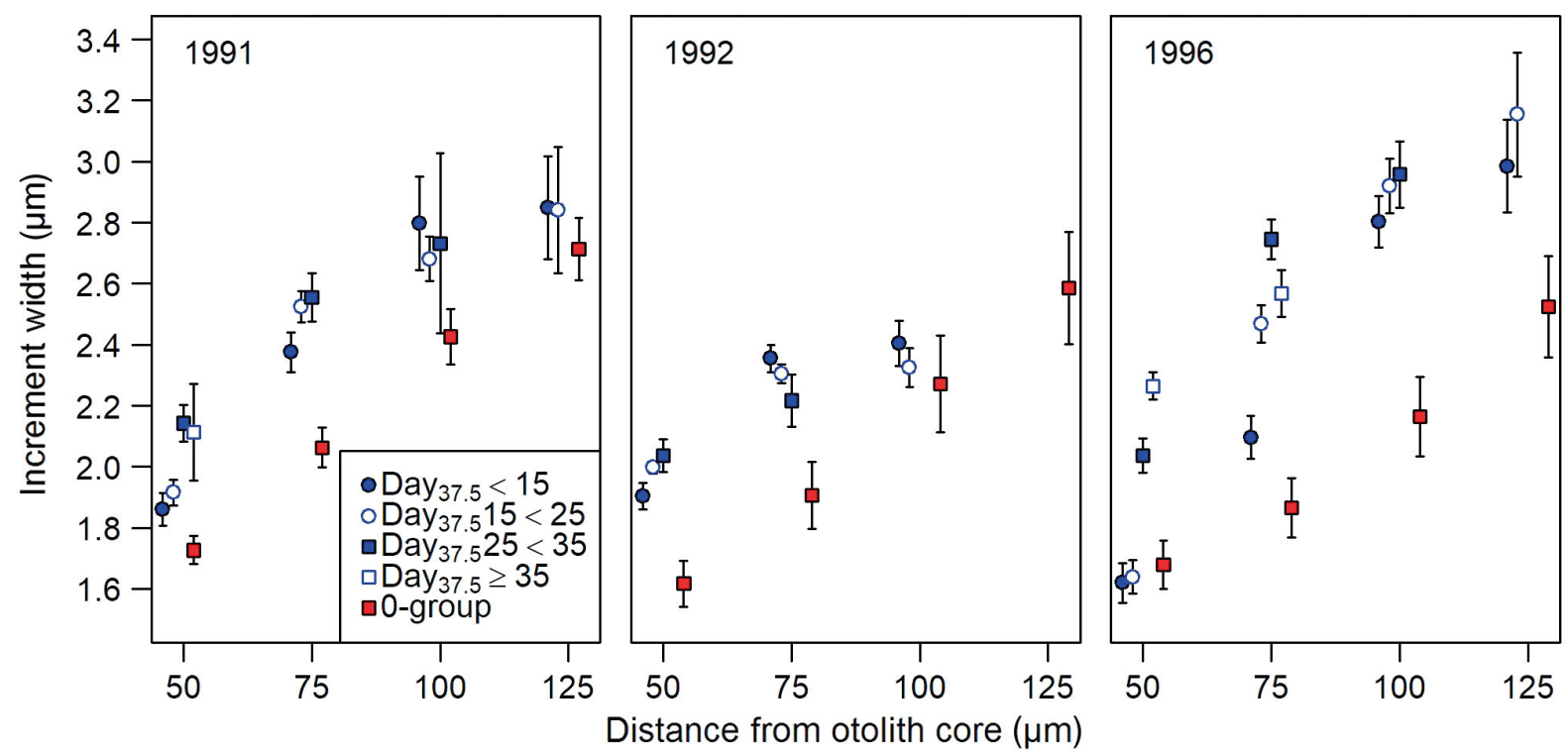

Fig. 6. Daily otolith increment width (mean $\pm 95 \% \mathrm{CI}$ ) related to the distance from the otolith core in Norwegian spring spawning herring larvae of different relative hatching day $\left(D a y_{37.5}\right)$ intervals and 0-group herring for the year classes 1991, 1992 and 1996. In 1991 the 0-group data from Barents Sea, fjords in the north and south are merged 


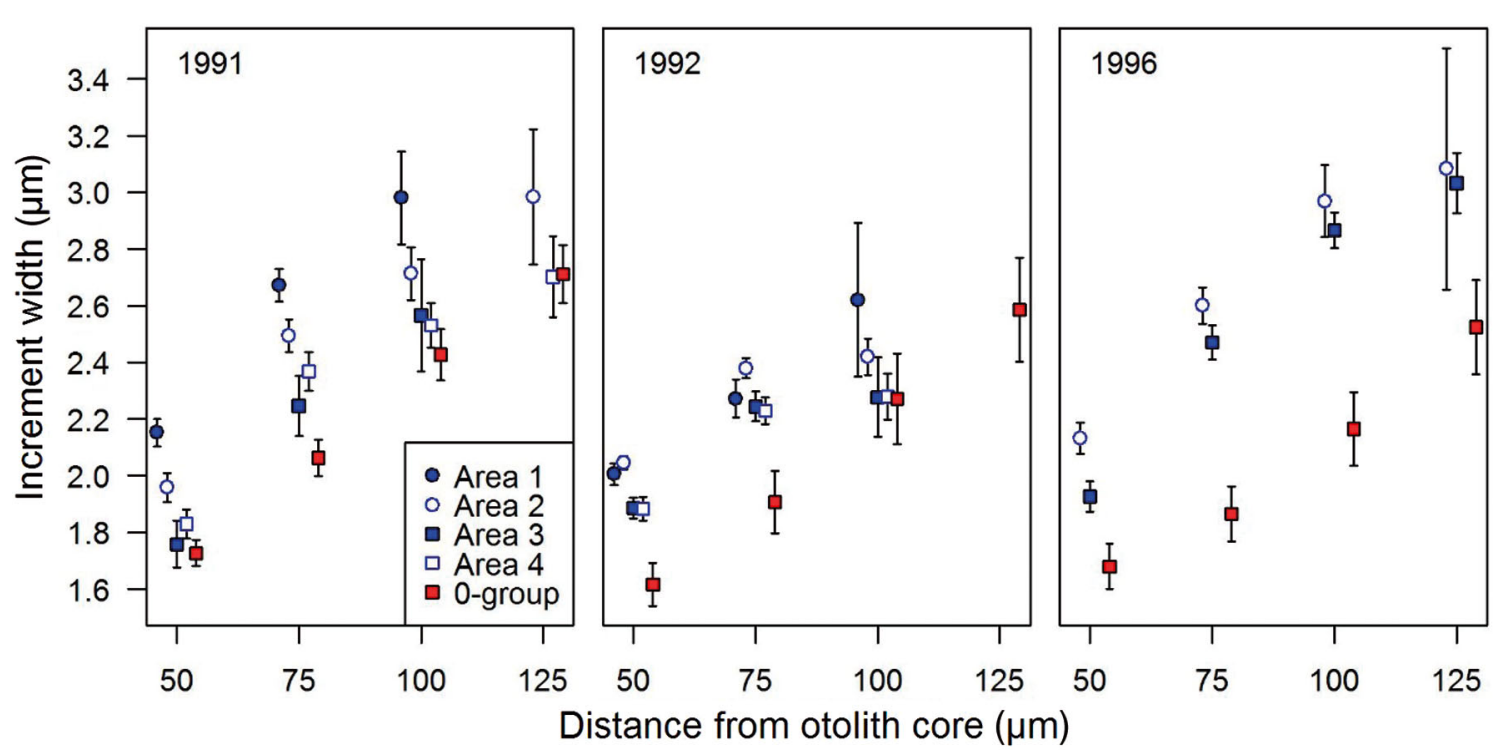

Fig. 7. Daily otolith increment width (mean $\pm 95 \% \mathrm{CI}$ ) related to the distance from the otolith core in Norwegian spring spawning herring larvae from different areas (see Fig. 2) and 0-group herring for the year classes 1991, 1992 and 1996. In 1991 the 0-group data from Barents Sea, and fjords in the north and south are merged
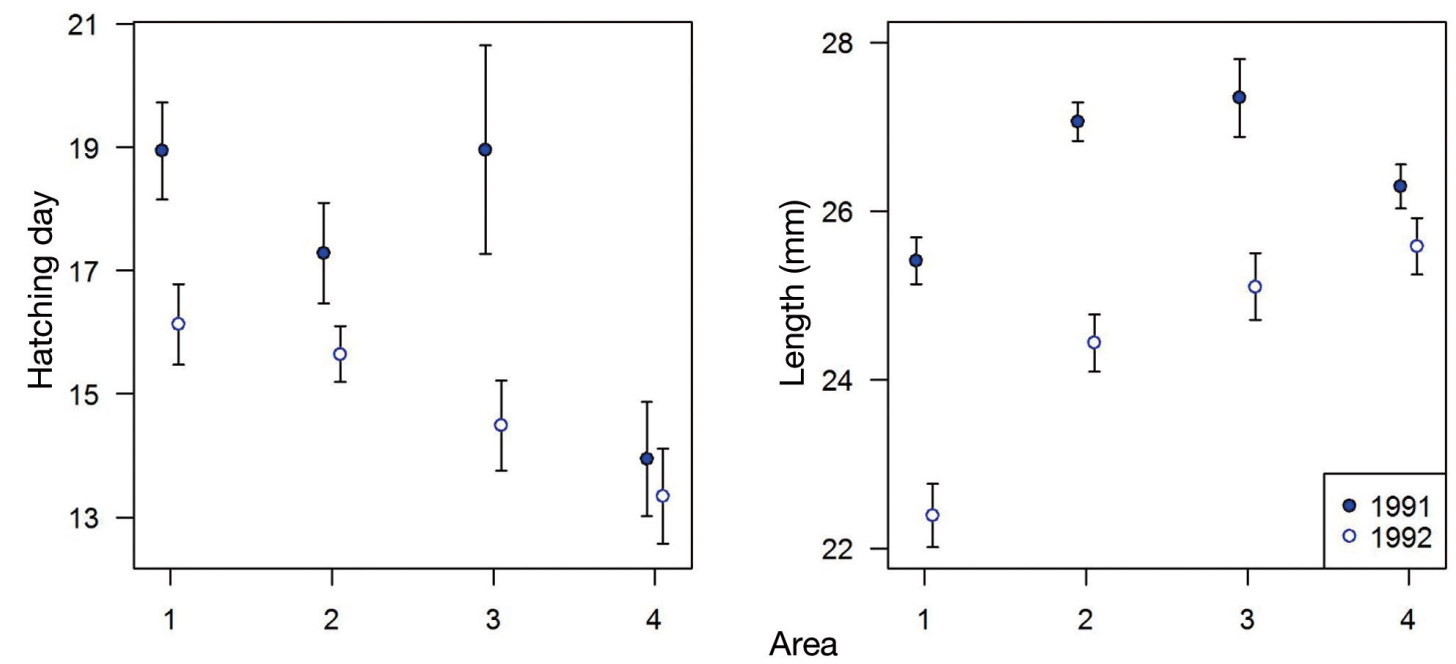

Fig. 8. Relative hatching day (Day $y_{37.5}$ ) and body length (mean $\pm 95 \%$ CI) of Norwegian spring spawning herring larvae in 1991 and 1992 related to sampling area (see areas in Fig. 2)

hatched and largest larvae tended to be found in the northeastern areas (Areas 3 and 4) (Fig. 8).

\section{DISCUSSION}

Daily otolith growth in NSS herring larvae, as measured at a distance from 37.5 to $137.5 \mu \mathrm{m}$ from the otolith core after the larvae reached approximate body length of $20 \mathrm{~mm}$, was significantly higher in larvae sampled on the Norwegian shelf in spring compared to the surviving population of 0-group herring sampled in the Barents Sea and fjords the following autumn. These differences in daily otolith growth can be interpreted as a selection for slow-growing larvae, which tend to hatch earlier in the year. Husebø et al. (2009) did not consider larval growth; they simply analysed several potential parameters and found that hatching time had the highest explanatory effect on recruitment, where early hatching in general led to higher survival of larvae. The results of the present study clearly support the conclusions in Husebø et al. (2009), but we also include new knowledge that the high survival in early- 
hatched herring is not an effect of high larval growth rates, as commonly found in fish (e.g. Takasuka et al. 2003). Observed differences in otolith growth between larvae and 0-group herring coincided with Husebø et al. (2009) both in years where there was early hatching and good recruitment (1991-1992) and in a year with late hatching and low recruitment (1996), suggesting that higher survival in earlyhatched and slow-growing larvae may be happening on a regular basis in this population.

The spatial analyses demonstrated that the size of the larvae increased towards the northeast, whereas hatching day tended to decrease in the same direction. The largest and earliest hatched larvae, found close to the coast in the north, were characterised by a low daily otolith growth over a distance of 37.5 to $137 \mu \mathrm{m}$ from the core, which was comparable to that observed in the ground and polished 0-group otoliths collected later in the autumn. This suggests that size, and to a lesser extent growth rate itself, may still be important, as early hatching also may result in earlier metamorphosis despite the slower growth. The slower growth is likely linked to lower ambient temperatures. Particle-tracking model simulations have predicted that larvae that hatch early have a drift route closer to the coast in lower water temperatures than larvae hatched later in the season (Vikebø et al. 2010). Even for larvae hatching later, these model simulations predict that individuals that drift quickly northwards and pass $68^{\circ} \mathrm{N}$ after $60 \mathrm{~d}$ of drift will occupy much colder water compared with those that drift more slowly. The larvae analysed in the present study all showed a rapid increase in daily otolith growth from 62.5 to $112.5 \mu \mathrm{m}$ followed by a decrease at larger distances from the core. In contrast, in the surviving 0-group population, the daily otolith growth increased more linearly over the otolith size range analysed. The model simulations of Vikebø et al. (2010) show similar differences in temperature trajectories between slow and fast drifting larvae, supporting the notion that daily growth observed in the surviving 0 -group is characteristic of fast drifting larvae. The large differences in daily otolith growth found between larvae and 0-group herring of the 1996 year class, even at larger distances from the otolith core, lend support to the hypothesis of high growth in larval retention areas on the shelf. Data from 1996 clearly demonstrated the high daily growth in late-hatching herring on the shelf south of $68^{\circ} \mathrm{N}$ as late as in June, a level of growth rate well above anything seen in the surviving 0 -group.

Further support for the effect of early and late hatching on daily otolith growth is provided by a pre- vious comparison of spring spawning herring populations in a coastal system in southern Norway (Berg et al. 2017). Mean width of daily increments at distances between 20 and $170 \mu \mathrm{m}$ from the otolith core were significantly higher in Landvik herring (peak spawning in May) compared with 2 other populations: Coastal Skagerrak spring spawners (peak spawning in March-April) and NSS herring (peak spawning in February-March), which are mixed in this area. The mean difference in daily otolith growth between the early and late spawners was approximately $0.5 \mu \mathrm{m}$ at a distance $75 \mu \mathrm{m}$ from the core, which is at the same level as observed between the larvae and the surviving 0-group herring in the present study. Also, the slow daily otolith growth observed by Berg et al. (2017) in the adult NSS spawning at the southern end of its latitudinal range was comparable to that found in the 0-group population of the present study.

There are several reasons why the larvae analysed in the present study may not be fully representative of the total population. In Husebø et al. (2009), particle-tracking model simulations were used to indicate that a significant proportion of the larvae may have drifted out of the survey area in the years 1991 and 1992, suggesting that the early-hatched and/or fastdrifting larvae were underrepresented. This could explain some of the large differences in the otolith growth rate distribution between larvae and the 0group herring in the present study. Therefore, even though the larvae found in the north may be representative of the early hatching and fast drifters, there is a possibility that larvae had drifted even further north and east, out of the survey area, and these larvae may have had daily otolith growth closer to that observed in the surviving 0-group population. In fact, the tendency of the 0-group to have some raw data measurements of low daily growth outside of that observed in the larvae, especially at distances of 62.5 to $112.5 \mu \mathrm{m}$ from the core, support the idea that some proportion of the early-hatched larvae already had drifted out of the larval survey area, and were underrepresented in the material.

A potential problem concerning the 0-group analysed is linked to the over-representation of fish from coastal rather than Barents Sea nurseries. Ideally, the samples should have been in proportion to the abundances in the nurseries (i.e. more fish from the Barents Sea than the fjords). However, the daily otolith growth observed in the fjords in 1991, 1992 and 1996 are probably representative of the early life history characteristics of the population surviving to the first autumn. This is supported by the observation that 
in 1991 there were no differences in daily otolith growth between 0-group herring in the Barents Sea and fjords in the south and north. The simulations by Vikebø et al. (2010) also indicated that the drift route of early-hatched larvae was typically closer to the coast and taking the larvae to nurseries in the Barents Sea faster than for late-hatched larvae. Vikebø et al. (2010) stated that the observed differences in drift between early and late hatching is linked to changes in the wind speed and direction. The same wind forces also increase the chances of earlyhatched larvae being dispersed into coastal and fjord areas rather than being dispersed westwards on the shelf, which will ultimately lead to early-hatching individuals being the predominant part of the 0group herring in the fjord nurseries.

The possibility that herring from outside of the main NSS herring population contributed significantly to the 0-group population analysed in the present study is considered to be very low. The 0group trawl sampling was carried out on significant acoustic registrations with size distributions typical for the NSS herring (Husebø et al. 2007), and there are no known local fjord populations in the 0-group sampling areas that could contribute to the observed biomass. The one population that is perhaps large enough to contribute with mixing is the summerautumn spawners (Husebø et al. 2005), which often overlap with NSS herring during feeding and wintering, but spawn at the northern coast 67 to $69^{\circ} \mathrm{N}$ in July-August. However, their larvae hatch very late in the year compared with the spring spawners, and would not have reached the same size in the autumn. This is also signified in their daily growth after hatching, which is very slow compared with the NSS herring (Husebø et al. 2005), with increments as low as $1.7 \mu \mathrm{m}$ at distances up to $100 \mu \mathrm{m}$ from the core; such patterns were not found in this 0-group material. In addition, their contributions are generally very low; it has been estimated that the recruitment to 0-group $\left(R_{0}\right)$ of summer-autumn spawners was below $1 \%$ of the recruitment of NSS herring in the 1991-1992 and 1996 year classes (Husebø et al. 2005).

The relevance of larval drift to survival of NSS herring was also pointed out by Skagseth et al. (2015). They found that recruitment of strong year classes of NSS herring occurs when there is a rapid transport from the spawning grounds to the northern nursery areas. Strong year classes such as 1950, 1959, 1983, 1991, 1992 and 2002 all had a wide northerly distribution into the Barents Sea (Holst et al. 2004). The mechanism behind the high survival could be a combination of temporal and spatial variation in preda- tion pressure between the coastal drift route and the nursery areas. The significance of hatching time for survival when there is temporal and spatial variation in overlap between predator and prey has also been pointed out by Litvak \& Leggett (1992). Higher survival among slow-growing, early-hatched larvae is also found in pollock Pollachius virens, haddock Melanogrammus aeglefinus and walleye pollock Theragra chalcogramma (Fortier \& Quinonez-Velazquez, 1998, Lapolla \& Buckley 2005, Nishimura et al. 2007) with some studies showing that selective predators may choose the largest individuals (Litvak \& Leggett 1992, Pepin et al. 1992, Takasuka et al. 2007). The results of the present study contradict the growthrate hypothesis, which combines feeding success and predation, and states that fast-growing individuals have a higher probability of survival compared to slower growing individuals (Campana 1996, Meekan \& Fortier 1996, Hare \& Cowen 1997, Payne et al. 2013). As suggested in Husebø et al. (2009), selection in NSS herring takes place for the earliest hatched and consequently the slowest growing individuals, which arrive early in the nursery areas prior to the increased predator levels developing northwards during spring warming.

In general, it is important to acknowledge that survival in fish larvae is influenced by several factors. The spawning of NSS herring and the larval drift seems to be adapted to the delay in the bloom with increasing latitude of $37 \mathrm{~d}$ within the spawning habitat of NSS herring (Vikebø et al. 2012); clearly a lack of overlap with prey for larvae may be very important. Most larval mortality likely occurs in the first couple of weeks, and here a match between elevated prey and growth rates is probably being selected for. The high mortality shortly after hatching is clearly demonstrated by the lack of correlation between early larval abundance indices and the abundance of age- 3 recruits of the same year class (Sætre et al. 2002a). Still, it is important to emphasize that the present study focused on mortality from the post-larval stage (20 to $30 \mathrm{~mm}$ body length) to the 0-group stage. Sætre et al. (2002a) demonstrated that abundance at the post-larval stage explained about $40 \%$ of the recruitment until age 3 , whereas abundance at the 0-group stage explained about $80 \%$. This suggests that there is still high mortality at the post-larval stage, and our hypothesis is that predation is the main reason for the lack of survival until 0-group stage. Predation is a complex and poorly understood factor (Pepin 2016). At the late larval stage, mortality caused by invertebrates decreases significantly, whereas the predation pressure from planktivorous 
fish increases (Pepin 2016). Although there is no conclusive evidence, there are some planktivorous fish that could potentially prey heavily on the NSS larvae given an overlap in time and space, such as blue whiting Mircomesistius poutasou (Monstad 2004), salmon Salmo salar smolts (Haugland et al. 2006), mackerel Scomber scombrus (Skaret et al. 2015), and saithe Pollachius virens (Bjørke et al. 1991), in addition to herring itself, which may contribute to high levels of cannibalism (Holst et al. 1997, Dalpadado et al. 2000, Prokopchuk \& Sentyabov 2006).

One common feature related to the occurrence of important predators in the drift route of the herring larvae is that it is often restricted to a relatively limited period due to the migration patterns and behaviour of the predators. Therefore, in general, early hatching and fast larval drift to the Barents Sea or into the fjords may reduce overlap with the main potential predators. On their feeding migration from spawning grounds to the west of Ireland, mackerel enter the Norwegian Sea and the Norwegian coastal area in June-July (Nøttestad et al. 2016). Blue whiting also migrate from the main spawning area southwest of Ireland to feed in the Norwegian Sea in the summer. Both mackerel and blue whiting are found along the Norwegian shelf in areas and times overlapping with herring larval drift (Utne et al. 2012, Skaret et al. 2015, Nøttestad et al. 2016). Husebø et al. (2009) used purse catch data on saithe to demonstrate that abundance of this stock along the drift route was high, with increasing activity in spring related to the warming of coastal waters. They demonstrated that the saithe tended to aggregate in schools, presumably actively feeding much earlier in the southern part of the distribution area than in the north, and herring larvae from an early hatching would have drifted past the main areas during periods of high feeding activities of saithe. This is comparable to the delay in phytoplankton blooms occurring northwards along the coast in spring (Vikebø et al. 2012). Puffins Fratercula arctica are also important predators that, during certain times of year and in some years, can consume large amounts of herring. In fact, it has been suggested that the year class strength for the NSS herring is determined after most of the herring larvae have drifted past the puffin colonies in July-August (Sætre et al. 2002a), so earlier arrival in the Barents Sea nurseries and reduced overlap with the puffins would be advantageous for the herring. Anker-Nilssen (1992) suggested that the puffins may constitute approximately $20 \%$ of the total consumption of 0-group herring.
High survival of a year class until 0-group stage may not necessarily lead to high recruitment into the fishery as adults, despite a significant relationship between the number of 0-group fish and recruitment. Growth of the 0-group until the adult stage may not follow larval growth, and the selection pressure related to size may vary accordingly. Several authors argue that variable mortality during the juvenile stage may account for a considerable part of the observed variability in recruitment (Sissenwine 1984, Smith 1985, Sparholt 1990). The mortality of NSS herring in the nursery areas is also of importance for recruitment to the spawning stock. To illustrate this, survival during the whole juvenile period from $4 \mathrm{mo}$ to 3 yr was estimated to range between 16 and $19 \%$ for the 1983, 1989, 1990 and 1991 cohorts, while for the 1984, 1985, 1988 and 1993 cohorts it was close to $0 \%$, and close to $10 \%$ for the 1992 cohort (Barros \& Toresen 1994, 1998, Barros et al. 1998). In the Barents Sea, Atlantic minke whale Balaenoptera acutorostrata (Lindstrøm et al. 2002), cod Gadus morhua (Johannesen et al. 2012) and harp seal Pagophilus groenlandicus (Johansen et al. 2004) are considered to be among the most important predators of juvenile herring. However, minke whales also feed heavily upon herring in coastal areas of northern Norway, especially when the herring produce strong year classes (Haug et al. 1993). Cod consumption on herring varies with the size of the capelin stock, and it has been suggested that cod is an important predator of herring juveniles in years with poor capelin recruitment (Barros et al. 1998, Godiksen et al. 2006), but it is probably not an important predator along the coast.

\section{CONCLUSIONS}

The present study has demonstrated that the earliest hatched larvae found in the north and close to the coast in May, and the surviving population of 0 group NSS herring during autumn, are characterised by similar slow daily otolith growth at comparable sizes, i.e. after reaching a body length of approximately $20 \mathrm{~mm}$, at a distance from 37.5 to $137.5 \mu \mathrm{m}$ from the otolith core. We argue that this indicates that early hatching and/or fast drift is important for larval survival. We suggest that increasing temperatures may have an indirect effect on recruitment of NSS herring, by inducing earlier spawning and hatching time, and that the potential mechanism behind high larval survival is most likely temporal and spatial variation in predation pressure between 
the larval drift route and the nurseries in the fjords and the Barents Sea. The occurrence of important predators like mackerel, blue whiting, salmon, saithe, herring (cannibalism) and puffins along the drift route of herring larvae is often restricted to a relatively limited period due to their migration pattern. By hatching early and/or drifting fast, the larvae may to tend to avoid overlap with these predators compared with those that hatch later. Hence, selection may take place for the earliest hatched and subsequently slowest growing individuals arriving early in the nursery areas prior to the increased predator levels developing northwards during spring warming. Size, and to a lesser extent growth rate, may still be important, as early hatching also may result in earlier metamorphosis despite their slower growth.

\section{LITERATURE CITED}

Anker-Nilssen T (1992) Food supply as a determinant of reproduction and development in Norwegian puffins Fratercula arctica. PhD thesis, University of Trondheim

Bailey KM, Houde ED (1989) Predation on eggs and larvae of marine fishes and the recruitment problem. Adv Mar Biol 25:1-83

Barros P, Toresen R (1994) Modelling age-dependent natural mortality of juvenile Norwegian spring-spawning herring (Clupea harengus L.). In: Hylen A (ed) Proceedings of the $6^{\text {th }}$ IMR-PINRO symposium, 14-17 June 1994, Bergen. Institute of Marine Research, Bergen, p 243-255

Barros P, Toresen R (1998) Variable natural mortality of juvenile Norwegian spring-spawning herring (Clupea harengus L.) in the Barents Sea. ICES J Mar Sci 55: 430-442

Barros P, Tirasin EM, Toresen R (1998) Relevance of cod (Gadus morhua L.) predation for inter-cohort variability in mortality of juvenile Norwegian spring spawning herring (Clupea harengus L.). ICES J Mar Sci 55:454-466

Berg F, Husebø Å, Godiksen JA, Slotte A, Folkvord A (2017) Spawning time of Atlantic herring (Clupea harengus) populations within a restricted area reflects their otolith growth at the larval stage. Fish Res 194:68-75

Bjørke H, Bakkeplass K, Hansen K (1991) Yngelundersøkelser i juli 1991 utenfor Norskekysten. Havforskningsinstituttets Egg- og Larve Program (HELP), rapport 42. Havforskningsinstituttet, Bergen

Caddy JF (1991) Death rates and time intervals: Is there an alternative to the constant natural mortality axiom? Rev Fish Biol Fish 1:109-138

* Campana SE (1996) Year-class strength and growth rate in young Atlantic cod Gadus morhua. Mar Ecol Prog Ser 135:21-26

Campana SE, Moksness E (1991) Accuracy and precision of age and hatch date estimates from otolith microstructure examination. ICES J Mar Sci 48:303-316

Dalpadado P, Ellertsen B, Melle W, Dommasnes A (2000) Food and feeding conditions of Norwegian springspawning herring (Clupea harengus) through its feeding migrations. ICES J Mar Sci 57:843-857

Folkvord A, Johannessen A, Moksness E (2004) Tempera- ture dependent otolith growth in Norwegian spring spawning herring (Clupea harengus) larvae. Sarsia 89: 297-310

Folkvord A, Høie H, Johannessen A, Solbakken T (2009) Effects of prey density, light regime and parental origin on growth and survival of herring larvae under controlled experimental conditions. ICES J Mar Sci 66: 1702-1709

Fortier L, Quinonez-Velazquez C (1998) Dependence of survival on growth in larval pollock Pollachius virens and haddock Melanogrammus aeglefinus: a field study based on individual hatch dates. Mar Ecol Prog Ser 174: $1-12$

Fossum P (1994) Aspects of recruitment with examples from commercially important fish stocks in Norwegian waters. PhD thesis, University of Bergen

Fossum P, Moksness E (1995) Recruitment processes of the 1991 year-class of spring spawning Norwegian herring (Clupea harengus L.) determined from otolith microstructure examination. In: Secor DH, Dean JH, Campana E (eds) Recent developments in fish otolith research. Belle W. Baruch Library in Marine Science No. 19, University of South Carolina Press, Columbia, SC, p 455-466

Fox CJ, Folkvord A, Geffen A (2003) Otolith micro-increment formation in herring Clupea harengus larvae in relation to growth rate. Mar Ecol Prog Ser 264:83-94

* Godiksen J, Hallfredsson EH, Pedersen T (2006) Effects of alternative prey on predation intensity from herring Clupea harengus and sandeel Ammodytes marinus on capelin Mallotus villosus larvae in the Barents Sea. J Fish Biol 69:1807-1823

Godø OR, Valdemarsen JW, Engås A (1993) Comparison of efficiency of standard and experimental juvenile gadoid sampling trawls. ICES J Mar Sci 196:196-201

*Hare JA, Cowen RK (1997) Size, growth, development, and survival of the planktonic larvae of Pomatomus saltatrix (Pisces: Pomatomidae). Ecology 78:2415-2431

* Haug T, Gjøsæeter H, Lindstrøm U, Nilssen KT (1993) Studies of minke whale Balaenoptera acutorostrata ecology in the northeast Atlantic: preliminary results from studies of diet and food availability during summer 1992. ICES CM 1993/N:7

Haugland M, Holst JC, Holm M, Hansen LP (2006) Feeding of Atlantic salmon (Salmo salar L.) post-smolts in the Northeast Atlantic. ICES J Mar Sci 63:1488-1500

Holst JC, Slotte A (1998) Effects of juvenile nursery on geographic spawning distribution in Norwegian springspawning herring (Clupea harengus L.). ICES J Mar Sci 55:987-996

Holst JC, Salvanes AGV, Johansen T (1997) Feeding, Ichthyophonus sp. infection, distribution and growth history of Norwegian spring-spawning herring in summer. J Fish Biol 50:652-664

Holst JC, Røttingen I, Melle W (2004) The herring. In: Skjoldal HR, Saetre R, Færnö A, Misund OA, Røttingen I (eds) The Norwegian Sea ecosystem. Tapir Academic Press, Trondheim, p 203-226

Houde ED (1987) Fish early life dynamics and recruitment variability. Am Fish Soc Symp 2:17-29

Houde ED (1989) Comparative growth, mortality, and energetics of marine fish larvae: temperature and implied latitudinal effects. Fish Bull 87:471-495

*Husebø A, Slotte A, Clausen LAW, Mosegaard H (2005) Mixing of populations or year class twinning in Norwegian spring spawning herring? Mar Freshw Res 56:763-772 
Husebø Å, Slotte A, Stenevik EK (2007) Growth of juvenile Norwegian spring-spawning herring in relation to latitudinal and interannual differences in temperature and fish density in their coastal and fjord nursery areas. ICES J Mar Sci 64:1161-1172

Husebø A, Stenevik EK, Slotte A, Fossum P and others (2009) Effects of hatching time on year-class strength in Norwegian spring-spawning herring (Clupea harengus). ICES J Mar Sci 66:1710-1717

ICES (2013) Manual for the midwater ring net sampling during IBTS Q1, Revision 2. Series of ICES Survey Protocols, SISP 2-MIK 2. International Bottom Trawl Survey Working Group, Copenhagen

Johannesen E, Lindstrøm U, Michalsen K, Skern-Mauritzen M, Fauchald P, Bogstad B, Dolgov A (2012) Feeding in a heterogeneous environment: spatial dynamics in summer foraging Barents Sea cod. Mar Ecol Prog Ser 458: 181-197

Johansen GO, Bogstad B, Mehl S, Ulltang Ø (2004) Consumption of juvenile herring (Clupea harengus) by cod (Gadus morhua) in the Barents Sea: a new approach to estimating consumption in piscivorous fish. Can J Fish Aquat Sci 61:343-359

Lapolla A, Buckley LJ (2005) Hatch date distributions of young-of-year haddock Melanogrammus aeglefinus in the Gulf of Maine/Georges Bank region: implications for recruitment. Mar Ecol Prog Ser 290:239-249

Leggett WC, Deblois E (1994) Recruitment in marine fishes: Is it regulated by starvation and predation in the egg and larval stages? Neth J Sea Res 32:119-134

Lindstrøm U, Haug T, Røttingen I (2002) Predation on herring, Clupea harengus, by minke whales, Balaenoptera acutorostrata, in the Barents Sea. ICES J Mar Sci 59: 58-70

* Litvak MK, Leggett WC (1992) Age and size-selective predation on larval fishes: the bigger-is-better hypothesis revisited. Mar Ecol Prog Ser 81:13-24

Meekan MG, Fortier L (1996) Selection for fast growth during the larval life of Atlantic cod Gadus morhua on the Scotian Shelf. Mar Ecol Prog Ser 137:25-37

Moksness E, Fossum P (1992) Daily growth rate and hatching-date distribution of Norwegian spring spawning herring (Clupea harengus L.). ICES J Mar Sci 49:217-221

Moksness E, Wespestad VG (1989) Ageing and back-calculating growth rate of Pacific herring (Clupea harengus pallasi) larvae by reading daily otolith increments. Fish Bull 87:509-513

Moksness E, Rukan K, Ystanes Y, Folkvord A, Johannessen A (1995) Comparison of somatic and otolith growth in North Sea herring (Clupea harengus L.) larvae; evaluation of growth dynamics in mesocosms. In: Secor DH, Dean JM, Campana SE (eds) Recent developments in fish otolith research. University of South Carolina Press, Columbia, SC, p 119-134

Monstad T (2004) Blue whiting. In: Skjoldal HR, Sætre R, Fernö A, Misund OA, Røttingen I (eds) The Norwegian Sea ecosystem. Tapir Academic Press, Trondheim, p 263-288

Mosegaard H, Madsen KP (1996) Discrimination of mixed herring stocks in the North Sea using vertebral counts and otolith microstructure. ICES CM 1996/H:17

Nedreaas K (1995) The inability of the 0-group saithe survey to forecast the strength of the year-classes entering the fishery. In: Hylen A (ed) Proceedings from the $6^{\text {th }}$ IMR-PINRO symposium. Institute of Marine Research,
Bergen, p 35-44

Nishimura A, Hamatsu T, Shida O, Mihara I, Mutoh T (2007) Interannual variability in hatching period and early growth of juvenile walleye pollock, Theragra chalcogramma, in the Pacific coastal area of Hokkaido. Fish Oceanogr 16:229-239

* Nøttestad L, Utne KR, Óskarsson GJ, Jónsson SP and others (2016) Quantifying changes in abundance, biomass and spatial distribution of Northeast Atlantic (NEA) mackerel (Scomber scombrus) in the Nordic Seas from 2007 to 2014. ICES J Mar Sci 73:359-373

* Payne MR, Stine DR, Worsøe Clausen L, Munk P, Mosegaard H, Nash RDM (2013) Recruitment decline in North Sea herring is accompanied by reduced larval growth rates. Mar Ecol Prog Ser 489:197-211

Pepin P (2016) Death from near and far: alternate perspectives on size-dependent mortality in larval fish. ICES J Mar Sci 73:196-203

* Pepin P, Shears TH, Delafontaine Y (1992) Significance of body size to the interaction between a larval fish (Mallotus villosus) and a vertebrate predator (Gasterosteus aculeatus). Mar Ecol Prog Ser 81:1-12

Pinheiro JC, Bates DM (2000) Mixed-effects models in S and S-PLUS. Springer, New York, NY

*Prokopchuk I, Sentyabov E (2006) Diets of herring, mackerel, and blue whiting in the Norwegian Sea in relation to Calanus finmarchicus distribution and temperature conditions. ICES J Mar Sci 63:117-127

R Core Team (2017) R: a language and environment for statistical computing. R Foundation for Statistical Computing, Vienna

* Sætre R, Toresen R, Anker-Nilssen T (2002a) Factors affecting the recruitment variability of the Norwegian springspawning herring (Clupea harengus L.). ICES J Mar Sci 59:725-736

Sæetre R, Toresen R, Søiland H, Fossum P (2002b) The Norwegian spring-spawning herring - spawning, larval drift and larval retention. Sarsia 87:167-178

Sissenwine MP (1984) Why do fish populations vary? In: May RM (ed) Exploitation of marine communities. Dalhem Workshop Report, Vol 32. Springer, Berlin, p 59-94

* Skagseth $\varnothing$, Slotte A, Stenevik EK, Nash RDM (2015) Characteristics of the Norwegian Coastal Current during years with high recruitment of Norwegian spring spawning herring (Clupea harengus L.). PLOS ONE 10: e0144117

* Skaret G, Bachiller E, Langøy H, Stenevik EK (2015) Mackerel predation on herring larvae during summer feeding in the Norwegian Sea. ICES J Mar Sci 72:2313-2321

* Slotte A (1999) Effects of fish length and condition on spawning migration in Norwegian spring spawning herring (Clupea harengus L.). Sarsia 84:111-127

* Slotte A, Johannessen A, Kjesbu OS (2000) Effects of fish size on spawning time in Norwegian spring spawning herring (Clupea harengus L.). J Fish Biol 56:295-310

Smith PE (1985) Year-class strength and survival of 0-group clupeoids. Can J Fish Aquat Sci 42:s69-s82

* Sparholt H (1990) Improved estimates of the natural mortality rates of nine commercially important fish species included in the North Sea multispecies VPA model. J Cons Cons Int Explor Mer 46:211-223

Takasuka A, Aoki I, Mitani I (2003) Evidence of growthselective predation on larval Japanese anchovy Engraulis japonicus in Sagami Bay. Mar Ecol Prog Ser 252:223-238

Takasuka A, Aoki I, Mitani I (2004) Three synergistic 
growth-related mechanisms in the short-term survival of larval Japanese anchovy Engraulis japonicus in Sagami Bay. Mar Ecol Prog Ser 270:217-228

Takasuka A, Aoki I, Oozeki Y (2007) Predator-specific growth-selective predation on larval Japanese anchovy Engraulis japonicus. Mar Ecol Prog Ser 350:99-107

Toresen R, Østvedt OJ (2000) Variation in abundance of Norwegian spring spawning herring (Clupea harengus, Clupeidae) throughout the 20th century and the influence of climatic fluctuations. Fish Fish 1:231-256

Utne KR, Huse G, Ottersen G, Holst JC and others (2012) Horizontal distribution and overlap of planktivorous fish stocks in the Norwegian Sea during summers 19952006. Mar Biol Res 8:420-441

Vikebø FB, Husebø Å, Slotte A, Stenevik EK, Lien VS (2010) Effect of hatching date, vertical distribution and inter-

Editorial responsibility: Susana Garrido (Guest Editor), Lisbon, Portugal annual variation in physical forcing on northward displacement and temperature conditions of Norwegian spring spawning herring larvae (Clupea harengus L.). ICES J Mar Sci 67:1948-1956

*Vikebø FB, Korosov A, Stenevik EK, Husebø A, Slotte A (2012) Spatio-temporal overlap of hatching in Norwegian spring-spawning herring and the spring phytoplankton bloom at available spawning substrata. ICES J Mar Sci 69:1298-1302

Wiebe PH, Morton AW, Bradley AM, Backus RH and others (1985) New developments in the MOCNESS, an apparatus for sampling zooplankton and micronekton. Mar Biol 87:313-323

Zuur A, Ieno EN, Walker N, Saveliev AA, Smith GM (2009) Mixed effects models and extensions in ecology with R. Springer, New York, NY

Submitted: September 1, 2017; Accepted: June 27, 2018 Proofs received from author(s): September 2, 2018 